\title{
IMPROVING STUDENTS' WRITING ABILITY \\ BYUSINGPROCESS-ORIENTEDAPPROACH \\ (An Action Research at Class VIII 1 of SMPN 1 Mawasangka)
}

\author{
La Mido \&Siti Safrina
}

(Dosen dan Mahasiswa Program Studi Pendidikan Bahasa Inggris, Unidayan)

\begin{abstract}
ABSTRAK
Tujuan penelitian ini adalah untuk meningkatkan kemampuan menulis siswa melalui Pendekatan Orientasi Proses pada SMP Negeri 1 Mawasangka.

Penelitian ini menggunakan desain Penelitian Tindakan Kelas dengan 2 (dua) saikel. Tahapan-tahapan dalam pelaksanaan penelitian ini yaitu perencanaan, tindakan, pengamatan dan refleksi. Alat yang digunakan untuk mengumpulkan data pada penelitian ini adalah lembaran observasi dan tes. Subyek penelitian berjumlah 30 orang yang terdaftar pada Tahun Akademik $2014 / 2015$.

Hasil penelitian menunjukan bahwa ada peningkatan terhadap kemampuan menulis siswa. Kemampuan menulis siswa dapat dilihat dari nilai saikel pertama sampai saikel kedua. yaitu pada saikel pertama, ada 55\% siswa yang mencapai nilai target minimum. Sedangkan pada saikel kedua, ada 80\% siswa yang mencapai nilai target minimum setelah mereka belajar menulis dengan menggunakan pendekatan Orientasi Proses.

Dapat disimpulkan dari hasil penelitian ini adalah bahwa ada peningkatan kemampuan menulis siswa karena persentase capaian yang diperoleh pada saikel kedua yaitu $80 \%$ dari jumlah siswa.
\end{abstract}

\section{INTRODUCTION}

Writing as one of four basic language skills that played the important role in term of teaching English as a foreign language in Indonesia.Ghaitzh (in Habirun, 2008) stated "there were some reasons for teaching writing to students of English as foreign language". First, through writing, students could communicate each other without face to face. Second, writing could also help students who have a problem in speaking. The last, writing was an activity of reinforcement, an enhancement of students' language development, and their learning style.

Beside the advantages of writing above, there were some problems that usually occur in writing. One of them was writing seemed the most difficult skill for students simply because writing need the clarity of expressing ideas. Jacobs et al. (1981: 66) stated "To get clear and effective, ideas should fulfill all the language aspects, such as, content, vocabulary, and organization“.
In line with above statement, Gebhard (2000: 34) explained "There were three problems faced by English as a Foreign Language (EFL) teacher in writing instruction". He divided them into three as followed: (1) the problem dealt with the teaching of the less-proficient students which tend to used ineffective writing strategies and the teacher showed the students how to write. (2) Students think that they could not write in English. Some students had negative attitudes on writing or lack of confidence as the writers. (3) The last was the teachers' response. Students generally did not paid attention to the teachers' comments and corrections to their written work. Thereby, the teacher should found an effective way in building students' self-confidence by which could change their negative attitude toward writing activities.

Based on observation and interview with the teacher conducted by the researcher 
on April 15 $5^{\text {th }}, 2014$ at SMP Negeri 1 Mawasangka at grade VIII 1, students seemed difficult to construct the writing draft. Firstly, in content, in writing students not yet concern with the idea or message, they were only writing what they think and not has attention in developing main idea so, not relevant with the supporting idea. Then, in vocabulary, students had less and used incorrect vocabulary, and sometimes students used Indonesian language in composing a recount text. Then, in language use, students do not used proper tense. After that, in mechanics students used error spelling and punctuation, as well as incorrect capital. The last, in organization students were difficulties to developed their ideas. In short, these showed that students had poor ability in content, vocabulary, language use, mechanics, and organization.

To make sure the credibility of these resources, researcher also employed diagnostic test on April 17 $7^{\text {th }}, 2014$ to seen and investigated students' weaknesses or problems concretely. The result indicated that students' writing ability was very poor. As stated by the teacher, the target minimum score which should be reached by the students indicating the success of teaching English was $65 \%$ of the total students got score 65.00. Basically such standard prevailed for each language skill. Therefore, the eight grade students of SMP Negeri 1 Mawasangka should have at least 65.00 as their minimum score for listening, reading, speaking, and writing. Yet, it was highly different from the fact taken from the result of diagnostic test. Based on the data, the eight grade students of SMPNegeri 1 Mawasangka got only 38.34 for the mean score for writing with none got 65.00 . In contrast, to meet the target minimum score it should be at least $65 \%$ of total students got 65.00. Thus, it could be stated that the students faced a big problems in writing.

All problems mention above might appear as a result of incompatible method used by the teacher in the classroom. Teacher applied in the classroom by asked students to read the personal recount text individually and then compose personal recount composition. Teacher just used monotonous conventional method which was start by giving exposure to writing types, providing one example which have existed in the book, and the last collecting the work without revising and proofreading.

Researcher assumed that above problems cause by the teaching and learning process in the classroom did not support the development of students' writing ability. Therefore, the students need to be taught by using newly challenging technique that supported their writing ability in order to solve the problems. With the aim of solving students' problems, the researcher offer interesting and challenging activities in teaching writing by applying Process-Oriented Approach to improved students' writing ability, in terms of content, vocabulary, language use, mechanics, and organization.

There were several reasons of using Process-Oriented Approach as the writing instructions in this study. Firstly, curriculum demand, in which students were require writing a texts (e.g. recount), which dealt with it was content, vocabulary, language use, mechanics, and organization. Secondly, it concern about the problems of students who could not applied their grammar competence into writing. Grabe and Kaplan (1996: 134) also stated "Process was an effective way in solving these problems because in ProcessOriented Approach, grammar was not taught separable with the context and the meaning". The character of process that was learning through imitation and analysis the understanding of learning could be achieved". Furthermore, process-oriented approach could give a positive impact on students' motivation in studying English as well as improving their writing ability.

Based on the above description, the researcher was quite motivate to conduct a study by using Process-Oriented Approach to improved students' writing ability at grade VIII 1 of SMP Negeri 1 Mawasangka "with 
problem statement is Can Process-Oriented Approach improves students' writing ability at grade VIII 1 of SMP Negeri 1 Mawasangka?

\section{Teaching Writing in EFL Context}

In EFL context, teaching and learning writing has purpose to get students to have ability on producing many kinds of written text, Ur (196). It could be said that in EFL teaching writing skill was appropriate to instruct the students to put their intention on recognizing and then producing a type of text. Genre means a type of text which was characterized by it was social function or in what purpose it was used, it was schematic structure or the text structure and it was language feature (Derewianka, 1992). It was really obvious in our curriculum used in Senior High School now, Kurikulum Tingkat Satuan Pendidikan (KTSP) which has some kinds of genre were taught, like descriptive, narrative, recount, argumentative, news item, etc.

However, writing was difficult skill for students, not only for EFL learner but for ESL learners as well. Moreover, to produce a coherent, wide range, and clear ideas of piece of writing were something that both native and non native speaker of a language never master (Nunan, 1999). Related to that point of view, Myles (2002) suggested that academic writing requires conscious effort, much practice, and experiences and simply she said that it must be practiced and learned trough experience. Thus, the writers' instructor (teacher) has to take into account both strategy to develop the language skill when working with their students.

\section{Aspects of Writing Ability}

Jacob et al. (1981: 66) mention five aspects of writing composition. They were content, vocabulary, language use, mechanics, and organization. The first was content which refers to the ideas or message conveyed. It involves development of a thesis or main idea, adequacy and relevance of supporting detail, demonstration of knowledge of the subject. Similarly, according to McCrimmon (1984) as indicates that content refer to subject of writing. Moreover, Jacob et al. (1981) note that this aspect was the most important in writing.

The second wasvocabulary. It involve sophisticated range with effective choice of words \& idioms, meaning not obscured by incorrect words, word choice not limited by lack of vocabulary, and appropriate word of register for topic.

The third was language use. It involve used of complex construction, few errors of agreement, tense, number, word order or functions, correct used of article, pronoun \& presuppositions, meaning not obscured by grammatical errors.

The fourth was mechanic. It involve mastery of conventions of spelling, punctuation, capitalization, meaning hard to grasp or totally obscured by lack of appropriate punctuation and/or speaking, paragraphing, demonstrates, coherence of ideas, hard writing is legible. Similarly, McCrimmon (1984) states that concerning mechanics the writer should pay attention to spelling, abbreviation, used of capital letters, hyphenation, used of italics and underlining, and forms of number.

The fifth or the last was organization. It involve fluent expression of ideas, not choppy or abrupt, logical sequencing, cohesiveness, main points, and supporting detail clearly and succinctly in writing includes the following activities, the list of ideas in the order the writer write them, looking for ideas that were similar or those that should follow one another of the outline of idea. So, they were listed in a logical order.

\section{Process-Oriented Approach in Teaching Writing}

In producing a piece of writing under process-oriented approach, the researcher also was concern in process of writing. Gere and Abbot (in Mappe, 2000:31) stated that the process of writing help students in writing 
groups to be reflective about what they did when they write, recognize problems, consider possibilities in a produced. It could be viewed as focusing more on selfexpression and discovery (Mappe, 2000:31). Students could write more effectively by examining their own creative processes through a few basic phases. In this process, students could be shown the different stages in the production of a piece of writing and be encouraged to discover what work best for them.

\section{DESIGN OF THE RESEARCH}

The design of this research was classroom action research. Action research was a form of self-reflective enquiry undertaken by participants (teachers, students or principals) in social (including educational) situations in order to improve rationality and justice of (a) their own social or educational practices, (b) their understanding of these practices, and the situations (institutions) in which the practices are carried out, Kemmis (1988: 2).

\section{Planning}

After analyzing problem encounter in the concern school, the researcher try to make planning on what were going to do in the action stage. Planning was a crucial stage in action research to connect the problem found in the field with the actions which were going to be applying. There were several activities which were compiling in this planning stage. These were could be seen as follows:

a. The researcher explain about the procedures and the benefits of ProcessOriented Approach to the English teacher of eight grade students in SMP Negeri 1 Mawasangka which were going to be apply in the teaching writing at the step of action. Afterwards, the researcher and English teacher consult the way to deal with the students' problems faced in teaching and learning writing at eight grade students under Process-Oriented Approach.

b. The researcher and the teacher cooperatively prepare and discuss about the lesson plan which were going to be apply in teaching writing in action stage. c. The researcher and the teacher would cooperatively set up the research instrument, which comprise observation sheet, note taking, and writing test to collect the data.

d. The researcher and the teacher discuss and provide the writing materials that were going to be utilize in teaching process.

e. The researcher and the teacher cooperatively prescribe the criteria of success in which the target of success in this research was $65 \%$ of the student get minimum scores 65 in writing tests.

\section{Action}

In this step, the researcher as the teacher would implement the action having been construct in the planning stage. Furthermore, the action stage was the direct and real stage to see whether this method could give progress for students' improvement in writing ability or not. Also, this was the stage where the researcher would teach students under Process-Oriented Approach, and where the students get involve as the subject of this research who would be think under the method being apply.

\section{Observation}

Observation was done along with applying action. This research would observe the condition of teaching writing under Process-Oriented Approach. It would observe the students' participation and activity in learning process, researcher's activity in teaching students and the way the researcher deals with the problem arises during teaching and learning process. Here, during observation, the researcher would fill out the 
observation sheet and take note regarding to action being apply.

In fact, in observation stage, there would be some factors which were going to be observed by the English teacher namely the conformity between the researcher's real activity in applying the concern approach and the plan activity of the teacher having been provide in the lesson plan. Also, students' result in writing activity under ProcessOriented Approach would be observed.

\section{Reflection}

Reflection was done at the end of the cycle. In reflection stage, the teacher and researcher would analyze the data use in observation stage as well as the result of students' work to get the overall understanding about the strength and the weaknesses found in the action. Furthermore, if the target of success have been achieve by the students, then, the researcher together with the English teacher would draw conclusion based on the data having been analyze. Otherwise, if the minimum target has not been achieve yet by the students, then, the researcher and the English teacher would revise the previous plan by making the subsequent constructively revise plan for the next cycle.

\section{Instruments of the Research}

The researcher used the instruments as in the following: 1) students' work was used to know the improvement of students' writing ability after Process-Oriented Approach used; 2) Observation sheets were employed to observe all activities during teaching and learning process in every meeting in each action stage. The observation sheet would be used for both teacher and students' ability during the implementation of Process-Oriented Approach; 3) Field note was used as the backing up data which would be taken into account in deciding the weaknesses and strengths in every meeting relate to the object of the study such as students' writing ability.
Furthermore, there were two kinds of data being collected in this study, namely qualitative and quantitative data. Qualitative data concerned about application of ProcessOriented Approach in teaching writing regarding to students activities in teaching learning process. The data was accumulated from the lesson plan, teaching materials, observation sheet, guideline interview, and note taking. Meanwhile, quantitative data was about improvement of students' writing ability as the result of applying this method.

There were several techniques for collecting data need in this research namely:

a. Writing Test

Students would be giving several writing tests by means of giving a topic and asking them to write a draft regarding to the topic. These tests would be carrying out at the end of each cycle to see the improvement of students writing under Process-Oriented Approach.

\section{b. Observation}

This would be done by observing teaching and learning process under ProcessOriented Approach by using observation sheet and field note in order to collect the qualitative data which show the researchers' and students' ability during the action.

c. Interview

The interview would be employ to get information about students' writing ability in that school. The researcher interview the English teacher to found out the level of students' writing ability. Besides, the researcher also interview students to know what the problems they faced in learning English especially writing.

\section{Technique of Data Analysis.}

There were two types of data which were going to be analyzed in this research namely:

a. Quantitative data were the data got from students' writing results which were going to be analyzed using descriptive statistics (mean score, percentage) that could be 
display through a table or graphic. It would be analyzed after the whole cycles were accomplished.

b. Qualitative data were gained from the process during the action, students' composition in process, and the strategies of researcher in dealing with the problems. It would be analyze qualitatively by means of observation and field notes.

These data would be analyze in three steps, they were:

a. Reduction. Researcher would analyze the quantitative data focusing to the objects being observe by the researcher (describe the data into number).

b. Data presentation. Researcher would analyze the qualitative data from the observation during the teaching and learning process (describe data into words).

c. Conclusion. After analyzing the data, researcher would draw a conclusion about the application of Process Oriented Approach in improving students' writing skill. After verifying the result, and then, the researcher would draw conclusions by means of descriptive presentation as the research report.

\section{FINDING AND DISCUSSION}

\section{A. Finding}

\section{Students' Evaluation Score in the First Cycle}

In the first cycle, there were 20 students who attended the class and got involved to compose a recount text in evaluation session. They were asked to write a text captioned "My Unforgettable Moment" by using their own words. They were asked to write the topic with length 100 words maximally. Researcher checked students' writing by using Jacobs et al band score in terms of content, vocabulary, language use, mechanics and organization. The students' total score in this first cycle was 1350 with mean score was 67.5. This showed that the target of this research had been achieved. But the researcher would do the next cycle to seen more the writing ability of students.

From the data above could be seen the improvement student's mean score in first cycle under chart.

Chart 4.1 The Students' Mean Score in Cycle 1

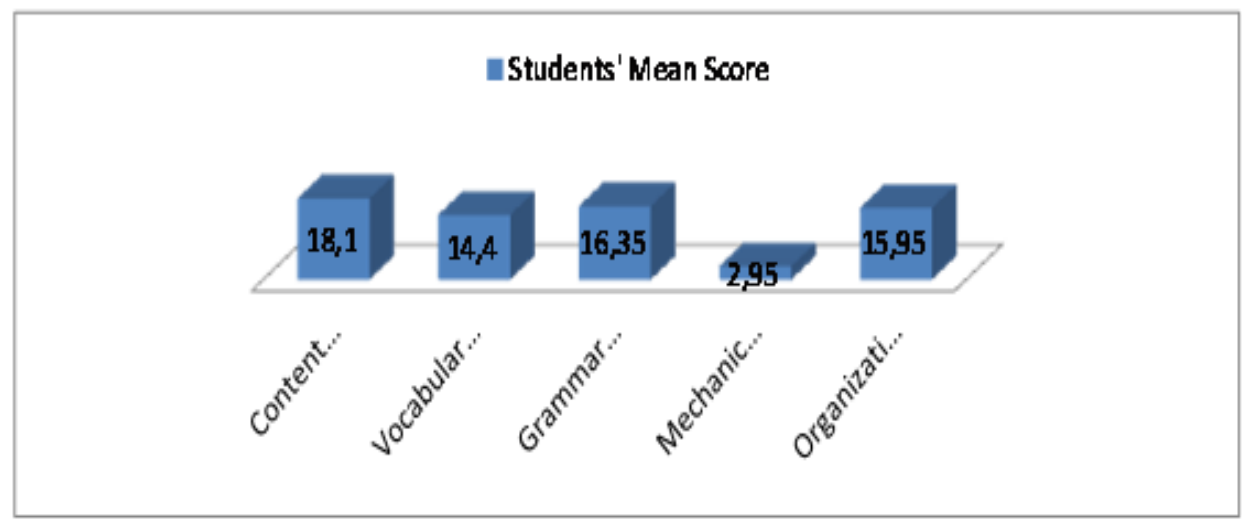

The data above showed the result of students' evaluation score for the first cycle. Where, in content aspect students' mean score was 18.1 with improvement
11.9 from 30 score that should got by students, vocabulary aspect students' mean score was 14.4 with improvement 5.6 from 20 score that should got by 
students, grammar 16.35 with improvement 8.65 from 25 score that should got by students, mechanics 2.95 with improvement 2.05 from 5 score that should by students and organization aspect was 15.95 with improvement 4.05 from 20 score that should by students. Overall, the total score for all aspects was 1350 in which they got the average score 67.5 which was categorized Fair.
Furthermore, we could see the mostly wrongness in grammar and few wrongness in mechanics. Even though their writing ability had already improved from the diagnostic test until evaluation session in cycle 1 , the target of this research had been achieved but still needed more increasing. So, the researcher would did cycle 2 to see the ability of students.

\section{Table 4.3 Students' Writing Achievement in Cycle 1}

The summary of students' writing achievement in the first cycle could be seen on the table below.

\begin{tabular}{cccc}
\hline $\begin{array}{c}\text { Number of } \\
\text { Students }\end{array}$ & $\begin{array}{c}\text { Percentage } \\
(\mathbf{\%})\end{array}$ & $\begin{array}{c}\text { Interval } \\
\text { Score }\end{array}$ & Categorized \\
\hline- & $0 \%$ & $100-88$ & Excellent to very good \\
5 & $25 \%$ & $87-75$ & Good to average \\
6 & $30 \%$ & $74-65$ & Fair \\
8 & $40 \%$ & $64-49$ & Poor \\
1 & $5 \%$ & $48-34$ & Very poor \\
\hline$\sum=\mathbf{2 0}$ & $\sum=\mathbf{1 0 0 . 0 0 \%}$ & \multicolumn{3}{|}{} \\
\hline $\begin{array}{c}\text { Percentage } \\
\text { of score } \geq \mathbf{6 5}\end{array}$ & & $\mathbf{1 1} \times \mathbf{1 0 0 \%}=\mathbf{5 5 \%}$ \\
\hline
\end{tabular}

By looking at students' achievement score above, the percentage of students that got score 65 minimally was $55 \%$. It showed that the target of the study had not been reached yet because it should be $65 \%$ of the total of students get score 65 minimally. In other words, there should be at least 16 students who got 65 in their writing score. In fact, there were just 11 students who could get the score 65. Therefore, the researcher and teacher concluded to conduct the second cycle.

\section{Students' Evaluation Score in Cycle 2}

In the second cycle, there were 20 students who attended the class and got involved to construct a recount text in evaluation process. They were asked to write a text with the topic "My Experience Last Holiday" by using their own words. They were asked to write the topic with length 100 words maximally. Researcher checked students' writing by using Jacobs et al band score in terms of content, vocabulary, language use, mechanics and organization. The students' total score in this cycle was 1560 with total mean score was 78 .

From the data above could be seen the improvement student's mean score of some aspects in second cycle in graphic. 
Chart 4.2 Students' Mean Score in Cycle 2

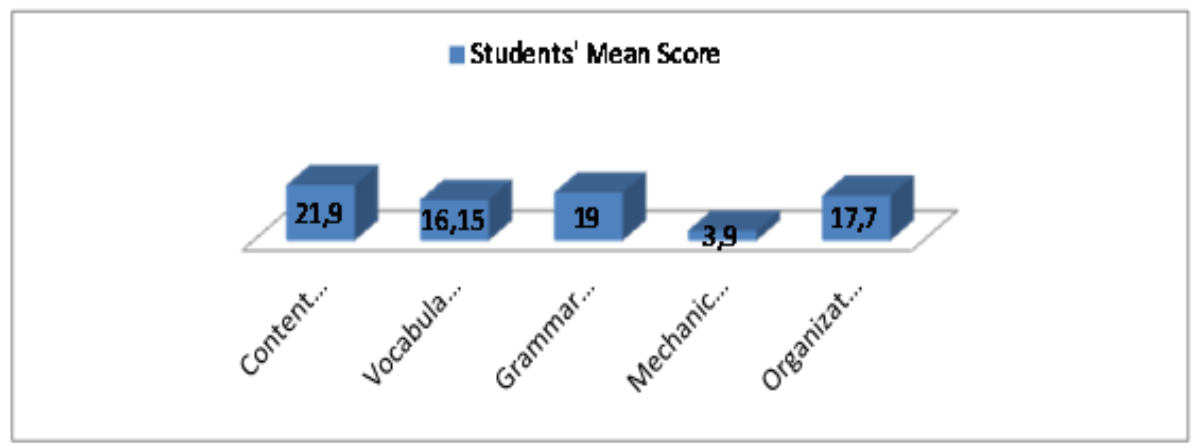

The data above showed the result of students' evaluation score for the cycle2. Where, in content aspect students' mean score was 21.9 with improvement score by students was 8.1 from 30 that should got by students, vocabulary aspect students' mean score was 16.15 with improvement score by students was 3.5 from 20 that should got by students, grammar 19 with improvement score by students was 6 from 25 that should got by students, mechanics 3.9 with improvement score by students was 1.1 from 5 that should got by students and organization aspect was 17.7 with improvement score by students was 2.3 from 20 score that should got by students. Furthermore, could be seen the mostly wrongness in grammar that decrease from 8.65 be 6 . Overall, the total score for all aspects was 1560 in which they got the average score 78 which was categorized Good-Average. The target of this research had achieved.

Table 4.4 Students' Writing Achievement in Cycle 2

\begin{tabular}{cccc}
\hline $\begin{array}{c}\text { Number of } \\
\text { Students }\end{array}$ & $\begin{array}{c}\text { Percentage } \\
(\boldsymbol{\%})\end{array}$ & $\begin{array}{c}\text { Interval } \\
\text { Score }\end{array}$ & Category \\
\hline 5 & $25 \%$ & $100-88$ & Excellent to very good \\
7 & $35 \%$ & $87-75$ & Good to average \\
4 & $20 \%$ & $74-65$ & Fair \\
4 & $20 \%$ & $64-49$ & Poor \\
- & $0 \%$ & $48-34$ & Very poor \\
\hline$\sum=\mathbf{2 0}$ & $\sum=\mathbf{1 0 0 \%}$ & & \\
\hline Percentage & & $\mathbf{1 6}$ \\
of score $\geq \mathbf{6 5}$ & & $\mathbf{2 0}$ & \multicolumn{3}{c}{} \\
\hline
\end{tabular}

By looking at students achievement score above, the percentage of students that got score 65 minimally was $80 \%$. It showed that the percentage is much higher than the target of the research that should be reached namely $65 \%$ of the total of students get 65 score minimally. Therefore, writer and teacher concluded to quit the research. However, there was two students who could not pass the target. The researcher consulted it with the English teacher and he decided that they would be given remedial test.

\section{B. Discussion}

1. Process-Oriented Approach was able to improve students' writing ability
a. Process-Oriented Approach improved students' writing ability in Content

Related to the content, Process Oriented Approach could 
improve students' ability in demonstrated their knowledge and convey information in a text. Clarity was an essential element of writing the earner should become skilled at in order to make his writing readable, and guarantee that those who read it understand exactly what he means to say (Starkey, 2004:). Furthermore, Murray and Hughes (2008) emphasize the importance of clarity as a fundamental element in making one's writing easy to be read and accessible. According to them, the key to achieve clarity is to make sentences short and to the point, the learner/writer should be relevant, make every word count, and try not to express more than one idea in each sentence. As highlighted by White and Arndt (1991), and marries quite well with the shift in primary focus inherent in the process writing approach from language, to ideas and content.

\section{b. Process-Oriented Approach improved students, writing ability in vocabulary \\ Related to vocabulary,} Process Oriented Approach could improve students' ability in choice of words and idioms, meaning and correct words. According to Starkey (2004) and Kane (2000) that the best way for the learner to accurately convey the ideas in writing is to choose the right words. Doing so ensures that the reader understands what the writer is really writing.

\section{c. Process-Oriented Approach improved students' writing ability in language use}

Related to language use, Process-Oriented Approach could improve students' ability in word order. The research findings showed that the students were able to apply the appropriate word order in their sentences. It was adduced by Fueling and Oldham (1998), "the right words (appropriate word choice) are necessary, but the order in which the writers place them in sentences determines how well they will do their job". It meant that the skill in positing the right words in the right place in sentences was very important. In other words, the better skill the students had in word choice should be followed by the better skill in word order.

\section{d. Process-Oriented Approach improved students, writing ability in mechanics}

Related to mechanics, Process-Oriented Approach had its unique step for getting over students difficulty in terms of the rules of writing. Furthermore, spelling was also become the common issue on students' difficulty for writing. Process-Oriented Approach with its unique strategies, basically, could handle it as well. Gould's 1999 study found the following: Spelling is also an issue when students hesitate when writing because they cannot spell the words and are not motivated to check a dictionary or reference. In these instances, provide them with a conventional spelling under one condition. They must put the spelling in their personal spelling dictionaries (spiral-bound notebooks work well). As the writing process progresses, each student will have more of the common words in a personal spelling dictionary, and they ask less often.

\section{e. Process-Oriented Approach improved students' writing ability in organization}

Related to mechanics, Process

Oriented Approach could improve 
students' ability in looking for ideas that are similar or those that should followed one another of the outline of idea. So, they are listed in a logical order. Kane (2000) and Creme and Lea (2008) among others, agree that coherence has a great role in making a good piece of writing. According to them, coherence has to do with arranging and linking one's ideas in a way that makes them most easily understood by the reader.

\section{Process-Oriented Approach was able to improve situation in the writing classroom}

In this research, Process-Oriented Approach was also able to improve the situation in the classroom. In teaching and learning process, the students took participation when they implemented Process-Oriented Approach in learning writing. The improvement of situation in the classroom covered the following situations:

\section{a. Process-Oriented Approach improved students' motivation towards writing}

It was proven by students' behavior that seldom complained when they were asked to write. The research findings showed that the students gave fewer complaints to the teacher. As stated by Ford and Wlodkowski in Elliot et al. (1993), "realistically, the best teacher can do is to make conditions as attractive and stimulating as possible".

\section{b. Process-Oriented Approach improved students' activeness}

The research findings showed that the students became more active. They were able to answer teacher' question and they also asked questions to the teacher. Vanessa Steele (in Chunling Sun, 2009) defines the process approach as focusing more on the varied classroom activities which promote the development of language use; brainstorming, group discussion, rewriting.

\section{Process-Oriented Approach improved students' behavior during teaching and learning process}

The research findings showed that the students paid attention to the teacher and they did not look bored or made noise. They even looked happy during the lesson. This was similar to Sheridan who stated," Children have short attention span but they would pay attention if you present the lessons in a brief but concise manner." The observation results of field notes which were supported by interview with students also showed that the differences of students' interest and behavior before and after employing Process-Oriented Approach. After the writer conducted the second cycle, she interviewed the eight grade students of SMP Negeri 1 Mawasangka. When the researcher asked the students' feeling, most of them said Process-Oriented Approach was good activities in learning writing. The students gave more attention and more participation in every single activity. The situation in teaching and learning process became conducive and made the students were able to write recount text easily. There were many important aspects in teaching writing using ProcessOriented Approach.

The process approach has had such a widespread influence on the teaching of writing throughout the English speaking world ever since (White and Arndt, 1991; Raimes, 1985; Zamel, 1983). However, in the last twenty years much discussion has been generated over which approach 
to teaching writing would be the best and process approach have always "dominated much of the teaching of writing that happens in the EFL classroom" (Badger and White, 2000: 153). According to Badger and White (2000) "writing in the process oriented approach mainly concerns linguistic skills, like planning and drafting and unlike the traditional product approach, there was much less emphasis on linguistic knowledge, like knowledge of grammar and structure of the written text. The process approach writing class also operates on the principle that L2 learners develop their writing skills unconsciously rather than learn the skills formally (ibid. 2000). Therefore the role of the teacher would be to facilitate the students' writing and to draw out their potential rather than to provide input or stimulus. In contrast to the traditional approach, the process approach is very much student-centered.

Process-Oriented Approach was one of alternative technique that was appropriate in teaching writing. It was proven by the result of students' improvement which passed the passing grade. The students participated in every single activity in joining the lesson also supported the activeness of conducting ProcessOriented Approach. Therefore, it was not necessary to put Process-Oriented Approach in doubt to improve students' writing skill. It was proven that Process-Oriented Approach could improve students' writing ability especially for eight grade students in SMP Negeri 1 Mawasangka.

\section{CONCLUSION AND SUGGESTION}

\section{A. Conclusion}

Based on the research findings, it could be concluded that Process-Oriented Approach improved students' writing ability. Students' writing ability in five aspects are content, vocabulary, language use, mechanics and organization improved well after they were taught effectively under ProcessOriented Approach. For further explanation, this improvement was proven by the findings after the research was conducted. The findings were:1) Students had sizeable progress in vocabulary in which they got easier in exploring ideas to write and got much more vocabulary after the research, 2) Students had significant improvement in language use in which they made fewer mistakes in composing recount text using simple past tense and were able to apply correctly all language features found in recount text as well as were able to use the appropriate word order in their sentences, and 3) Students found it easier in writing text using correct spelling, capitalization and punctuation.

\section{B. Suggestions}

Writing for most students was considered to be a difficult subject. Related to the research process, the students often complained when they were asked to write. It deals with the way of the teacher in teaching writing. Teachers have to use compatible technique and method. Otherwise, the students will get bored then fail in the subject. That was why teachers should apply ProcessOriented Approach in teaching writing. By using the method, the students will not be bored. Automatically the teaching and learning process could run smoothly and the objectives can be achieved.

Teaching and learning process need participation from both students and teachers. Whatever the method and whoever the teacher if there is no participation within the class, there will be no improvement in students' ability. Therefore, the students should practice this Process-Oriented Approach by themselves at home so that their writing ability got better and better. 


\section{BIBLIOGRAPHY}

Derewianka, B. 1992.Exploring How Text Work. Newton, NSW: Primary English Teaching Association. Australia.

Gebhard, J.G. 2000.Teaching English as Foreign or Second Language: Ateacher Self-Development and Methodology Guide. Ann Arbor: The University of Michigan Press.

Grabe, Williams \& Robert B. Kaplan. 1996. Theory and Practice of Writing. United States of America. Addison Wesley Longman.

Habirun, 2008.The Implementation of Process Writing to Improve the Writing Ability of the Eighth Grade Students.Unpublished thesis. Malang: State University.

Jacobs, H. L. Stephen, Deanna, V. Faye, Jane. 1981. Testing ESL Composition Profile: A Practical Approach. Rowley, London, Tokyo. Newbury House Publisher.

Kemmis, S. dan MC. Toggart.R. (Ed.1988). The Action

Resesarch
Planner.Deakin.Deakin University: Australia.

Mappe, Syahrir, 2000. A comparative Study of the Teaching of Writing to The Indonesian University Students' Under Two Instructional Modes. Singapore. Unpublihshed Thesis.

McCrimmon, J.M. 1984. Writing With a Purpose. Eight Edition. Boston. Houghton Mifflin.

Myles, J. 2002. Second Language Writing and Research: The Writing Process and Error Analysis in Students' Texts. Volume 6/2. Queen's University. http://www.kyoto-

su.ac.jp/information/test-cj/cj22/al html, Retrieved on $14^{\text {th }}$ January 2012.

Nunan, D. 1999. Second Language Learning and Teaching. Heinle \& Heinle Publishers.

Ur. Penny. 1996. A Course in Language Teaching Practice \& theory. Cambridge University Press. 
